\title{
RESEARCH NOTES
}

\section{Electoral Participation, Ideology, and Party Politics in Post-Communist Europe}

\author{
Robert E. Bohrer II \\ Gettysburg College \\ Alexander C. Pacek \\ Texas A\&M University \\ Benjamin Radcliff \\ University of Notre Dame
}

The relationship between voter participation and party fortunes has received much attention in the voting behavior literature. Specifically, a number of studies on the advanced industrial democracies postulate that left-of-center parties benefit from higher turnout. This article extends that argument to a quite different context: the economically and politically volatile post-communist world. Using aggregate data from 15 post-communist countries between 1990 and 1999, we test the turnoutparty vote linkage. We find that, indeed, increased turnout benefits left parties, particularly the successor communist parties, while adversely affecting conservative and nationalist parties.

\begin{abstract}
A the transition from communism continues across Europe, scholarly attention remains focused on several closely related issues. Both country-specific and cross-national analyses examine the forces that drive mass participation and electoral choice in an environment where they are no longer mandated by the state (Bahry and Way 1994; Heyns and Bialecki 1991; Millard 1992; Pacek 1994; Powers and Cox 1997; Sakwa 1995; Wade, Lavelle and Groth 1995; Whitefield and Evans 1994). Scholars also continue to assess the determinants of the electoral success of the ex-communist and other successor parties (Haraszti 1995; Ishiyama 1995; Mahr and Nagle 1995; Moraski and Loewenberg 1999; Rose 1997; Zubek 1994). Other studies focus directly on party identities and their ideological appeals to various segments of the population (Janos 1994; Kitschelt 1992; Kolosi et al. 1992; Korosenyi 1992; Markowski 1997). While the literature has made important contributions to our understanding of post-communist electoral politics, important questions remain unanswered.
\end{abstract}

The authors wish to thank those who assisted with the manuscript in various stages, including the anonymous reviewers and (in alphabetical order) Edwin Eloy Aguilar, Belinda Bragg, J. Sky David, Amy Gille, Lance Leloup, Carol Leff, and Guy Whitten.

THE JOURNAL OF POLITICS, Vol. 62, No. 4, November 2000, Pp. 1161-1172

(C) 2000 Blackwell Publishers, 350 Main St., Malden, MA 02148, USA, and 108 Cowley Road, Oxford OX4 1JF, UK. 


\section{Robert E. Bohrer II, Alexander C. Pacek, and Benjamin Radcliff}

In this article we address one such matter: Do shifts in the rate of electoral participation affect vote shares for different types of political parties in volatile environments? The idea of a link between participation and party fortunes is commonplace in Western democracies and has received increasing attention in the global voting literature (e.g., Lijphart 1997). We examine this issue in the context of parliamentary (lower house) elections between 1990 and 1999 in 15 post-communist countries.

\section{Taking Stock}

The voting behavior literature is replete with debates over the extent and consequences of unequal voter participation (see Radcliff 1992 and Lijphart 1997 for extensive reviews). One of the controversies involves the connection between turnout and party vote shares. A number of empirical studies argue that increases in turnout work to the benefit of nominally left-of-center parties in the United States (Radcliff 1994, 1995; Tucker and Vedlitz 1986), Australia (McAllister 1986), New Zealand (Nagel 1988), and to a lesser extent, Britain (McAllister and Mughan 1986). Cross-national studies on advanced industrial democracies (Pacek and Radcliff 1995) and developing countries (Aguilar and Pacek 1997) also demonstrate this relationship. Others dissent. Rose (1997) argues that the political impact of nonvoting is overexaggerated: nonvoters do not differ appreciably from the general voting population, and overall levels of turnout would have to be "abnormally low" for shifts in turnout to have any measurable party impact. Similarly, Erikson (1995a, 1995b) and Nagel and McNulty (1996) both challenge the notion that higher turnout benefits the Democrats in the United States.

Radcliff (1994) nicely summarizes the theoretical basis for this relationship. The lower- and working-class citizens who form the traditional core constituencies of leftist parties tend to vote at lower and more variable rates than their better-off counterparts who are the core supporters of center and right parties. As the relatively well-off tend to vote more consistently and at higher rates, interelection variations in turnout primarily represent increases in turnout among the natural constituencies of the left. To the extent that these newly mobilized voters do indeed vote disproportionately for the left, increased turnout translates into a greater share of the vote for leftist parties. While the logic is perhaps most applicable to low-turnout countries such as the United States, where the socioeconomic differences in participation are especially pronounced, a "classbias" in turnout has been reported for other countries (e.g., Oppenhuis 1995, 186-90; Seligson et al. 1995, 166-71; Dalton 1996, 57-8), even where compulsory voting rules are in effect (McAllister 1986).

Rosenstone (1982) offers a related but distinct argument. Economic adversity, he argues, reduces the capacity of citizens to bear the costs of political participation. As adversity is rather more likely to affect the nonaffluent citizens (e.g., Weatherford 1978) who are the presumptive constituents of the left, the effect of economic dislocations such as unemployment further reinforces the class 
bias in turnout. Inasmuch as economic conditions in virtually the entire postcommunist world have been turbulent, the depressive effects on the participation of the less well-off are likely to be amplified. If so, we would expect to find the relationship between turnout and the leftist vote to be especially pronounced.

That said, on its face the post-communist world would appear to differ in other important respects from the Western industrial democracies. For decades voter turnout was mandated by the state, the overall class structure varied from that in the West, and the dominant communist parties scarcely resembled the social democratic, labor, or even the politically relevant communist parties in Western Europe. Still, a number of important developments occurred during the postcommunist decade that render the turnout-vote logic more appropriate for this region. Many of the former ruling communist parties managed, in part, to shed the weight of their past by positioning themselves as credible defenders of the working class and other disadvantaged groups during the often painful economic transition. (Mahr and Nagle 1995, 401-402; Tworzecki 1996, 70; Zubek 1994, 824-25). Moreover, the relatively muted social inequities of the past have given way to very real socioeconomic discrepancies that have (to varying degrees) turned the prior relatively egalitarian societies into more conventional class societies. Certainly all agree that the transition from communism has created a division in society between those who have benefited and those who have lost. Unskilled workers, elderly pensioners, state workers, and women have done poorly; white-collar workers, civil servants, and the self-employed have adjusted more successfully (Blazyca 1998, 208; Cox 1998, 227; Mackie 1995, 183; Plasser, Ulram, and Waldrauch 1998, 183-84).

How might the turnout-vote relationship, then, manifest itself in the postcommunist environment? First, it appears that party allegiances among voters are solidifying (again, to various degrees across individual countries) according to social groups and classes. Some scholars posit that individuals with low skill levels support parties that promise the most protection from market forces, while those with high skill levels are likely to vote for more pro-market parties (Evans and Whitefield 1993; Kitschelt 1992; Mackie 1995). Other studies tend to confirm these expectations. Plasser, Ulram, and Waldrauch (1998), for example, note that the differences between those who vote for ex-communist and other leftist parties on the one hand, and those favoring liberal or conservative parties on the other, are striking: "Liberal and conservative preferences are wellestablished among entrepreneurs, white collar workers, and civil servants ... Ex-communists and other left parties find few supporters here, instead drawing upon the considerable reservoir of working class and senior citizens ... Noncommunist social-democratic parties also have a proportionately higher number of elderly and low income voters" $(1998,156-7)$. Second, there is ample evidence of greater abstention rates among the working class and disadvantaged than among the better-off in a number of countries, including Hungary (Kolosi et al. 1992, 144-7), Poland (Cline 1993; Jasiewicz 1993; Markowski 1993; Wade, Lavelle, and Groth 1995, 414-15), Lithuania (Girnius 1992, 6-12), and Russia (Whitefield and Evans 1994). 


\section{Robert E. Bohrer II, Alexander C. Pacek, and Benjamin Radcliff}

In sum, the general theoretical conditions necessary for a nexus between the rate of electoral participation and party vote shares appear to obtain in postcommunist Europe. In what follows, we attempt to provide empirical evidence in support of the contention that such does in fact exist.

\section{Data and Method}

We analyze the relationship between turnout and party support in the conventional manner: Party vote shares are regressed upon turnout and a set of relevant control variables across space and time (e.g., Radcliff 1994; Nagel and McNulty 1996; Aguilar and Pacek, 1997). The analysis relies on the universe of competitive legislative elections held in post-communist Europe from 1990 through 1999. Voter turnout is the percentage of the age-eligible population actually casting ballots at the time of election. ${ }^{1}$

We begin with the onerous task of fashioning a meaningful categorization of political parties along ideological lines. As our argument suggests that party fortunes vis-à-vis turnout differ with the party's position in the ideological space, we must of necessity assign parties to such positions. This endeavor is fraught with difficulties. The specification of coherent ideological positions in postcommunist Europe is itself problematic, in that the politics of the region hardly corresponds to the (relative) ideological purity of Western Europe. Put differently, it is, first, difficult to specify a set of noncontroversial ideological categories to which parties might be assigned. Further, once such a typology is established, ambiguities will necessarily remain. To take but one example of differences of opinion about the ideological stance of relevant parties, Ishiyama (1997) refers to the Croatian Social Liberal Party (HSLS) as the "principal left competitor" of the ex-communist SPH/SDP, while Day, German, and Campbell (1996) and Banks, Day, and Muller (1998) both label it a "liberal-centrist" party.

Nonetheless, few would argue that post-communist nations are in a state of complete ideological disorder. Despite some admittedly problematic cases, there seems to be a rough consensus on the broad ideological contours of party systems. We adopt as our reference point a conventional six-point ideological scale

\footnotetext{
${ }^{1}$ The countries and elections used in our study are Albania (1992, 1996, 1997), Bulgaria (1991, 1994, 1997), Croatia (1992, 1995), the Czech Republic (1992, 1996, 1998), Estonia (1992, 1995, 1999), Hungary (1994, 1998), Latvia (1995, 1998), Lithuania (1992, 1996), Moldova (1994, 1998), Poland (1991, 1993, 1997), Romania (1992, 1996), Russia (1993, 1995), Slovakia (1992, 1994, 1998), Slovenia $(1992,1996)$, Ukraine $(1994,1998)$. These represent cases used in the subsequent analysis; there is actually one additional case per country that is consumed by the use of the lagged dependent variable. Data were not available for Latvia (1993). We also excluded the federal Republic of Yugoslavia and former Soviet republic of Belarus due to excessive fraudulent electoral practices. Party vote data are from published national election statistics. Turnout data for 1990-1997 elections are from Voter Turnout from 1945-1997: A Global Report (1997). Turnout data for 1998 and 1999 elections are computed from national election statistics and census data for voting age populations. Note that the results are similar when excluding the post-1997 cases; the only appreciable difference is that the turnout coefficient for conservative parties in Table 1 (colume (e)) and Table 2 (column (e)) becomes significant (while remaining negative).
} 
from left to right (ex-communist, non-communist left, liberal-centrist, centerright, conservative, and nationalist), based on party classifications from Day, German, and Campbell (1996).

Given the lack of absolute agreement on party placement, we compared the coding from this source with two others: Banks, Day, and Muller (1998) and the Elections Around the World web site. In a minority of cases, these sources disagreed. In these instances, we of necessity made an assignment based upon the literature and our own assessment, drawn in part from party programs and statements. ${ }^{2}$ The empirical results reported below are unchanged when we exclude from the analysis the cases that include data for these four parties.

To further validate our coding scheme, we compared our classification to the 10-point left-right scale ( 1 being "most left" to 10 being "most right") used by Huber and Inglehart (1995). Although only nine of the fifteen countries in our study were included in their analysis, averaging their scores for the countries and parties that correspond with our sample illustrates that our classification shows exactly the sort of movement from left to right across the ideological space that we would expect. The averaged scores of the parties in our sixfold classification on their scale are as follows: ex-communist (3.06), noncommunist left (3.92), liberal-centrist (5.10), center-right (5.99), conservative (7.27), and nationalist (7.40). We are thus reasonably confident in the validity of our categorization.

Although we think this categorization reasonable and defensible, in what follows we are at pains to demonstrate that our statistical results are robust. This provides what is perhaps the best possible vindication of our coding scheme: If we can demonstrate consistent results in the face of changes in sample, model specification, and estimation technique, we can be relatively secure in believing that the results are not artifacts of a flawed system of ideological categorization.

\section{Analysis}

The basic model treats the percentage share of the vote for each party grouping as a function of turnout and (to control for electoral history and autocorrelation) the first lag of the dependent variable. To account for the fact that one of the most obvious elements in electoral competition in post-communist systems has been the tendency for almost all incumbent governments to lose votes, we also include a dummy variable coded one when a party from the given ideological category was part of the government and zero otherwise. Given the general propensity for voters to hold governments accountable for economic performance, we also include the election year change in real per capita GDP (unless, following Pacek and Radcliff, 1995, the election occurs early in the cal-

\footnotetext{
${ }^{2}$ The relevant cases are the Hungarian Democratic Alliance - RMDZS (Romania, coded "nationalist"), the Movement for a Democratic Slovakia-HZDS (Slovakia, "nationalist"), the Slovene Social Democratic Party - SDSS (Slovenia, "nationalist"), and the Coalition Party and Rural People's Union-KMU (Estonia, "noncommunist left").
} 


\section{Robert E. Bohrer II, Alexander C. Pacek, and Benjamin Radcliff}

endar year, in which case we use the prior year's change) and an interaction between this term and the incumbency variable. ${ }^{3}$ To control for the pooled structure of the data, we include dummies for each country (excepting a reference category). The purpose of the dummies is twofold. First, they fulfill the econometric purpose of accounting for unit-effects, meaning large and sustained differences in the level of the dependent variable across spatial units. The dummies control for such by fitting separate intercepts for each country. In so doing, they also control for the sundry country-specific factors that might cause the general level of votes for the different parties to vary from nation to nation.

Given the small number of time points per country, we report conventional OLS results. All reported findings are unchanged, however, using either robust standard errors or panel corrected standard errors.

Preliminary results are in Table 1 for each party grouping. As is apparent, the ex-communist and the noncommunist left have positive coefficients, although the latter is statistically insignificant and trivial in magnitude. The remaining four categories all have negative coefficients, though only for the nationalists is it significant and large enough to warrant attention. The implication is obvious: The principal winners and losers from increased voter turnout are the ex-communist and nationalist parties, respectively. ${ }^{4}$

It is possible, of course, that our six-category assignment is cutting too finely. Should, say, the nationalist vote be treated separately from the conservative? Should liberal-centrist parties be so clearly distinguished from the center-right? To that end, we performed the same analysis when collapsing to three categories: total-left (ex-communist and noncommunist left), total-center (liberal and center-right), and total-right (conservative and nationalist). Initial results (not shown) indicate a positive, significant effect for the total-left, a negative but insignificant effect for the center, and a negative, significant effect for the right. ${ }^{5}$

To test for stability, we reestimated all of the above models when using robust regression. This technique is designed to produce results that are relatively

\footnotetext{
${ }^{3}$ Economic data are from The World Bank. GDP is measured in 1998 constant purchasing power parity.

${ }^{4}$ There are a few cases where the vote (or its lagged value) for a given party grouping was zero, given the absence of appropriate parties contesting the election. Excluding these cases has no effect on the reported results. Vote share is, except as noted presently, the percentage received in voting for party lists. In three cases the electoral arrangements changed between elections so that the lagged value of the vote depends upon either all single-member districts (SMD) or a different combination of proportional representation (PR) and SMD: Albania 1992, Bulgaria 1991, Russia 1993. In addition, Ukraine relied entirely upon SMD through 1994, adopting partial PR for the 1998 elections. Hence the lagged value for the latter election suffers from the same potential problem as those discussed above. However, omitting all four of these cases has little effect on the reported results; the principal effect is to increase substantially the magnitude of the ex-communist and total-left coefficients.

${ }^{5}$ We examined two other possible grouping schemes: a center consisting of liberal, center-right, and conservative (leaving the nationalists alone on the right) and a right consisting of nationalist, conservative, and center-right (leaving the liberals alone in the center). Neither of these produced statistically significant coefficients.
} 
TABLE 1

Turnout and Party-Vote

Post-Communist Countries 1990-1999

OLS Estimates

\begin{tabular}{lcccccc}
\hline & $(\mathrm{a})$ & $(\mathrm{b})$ & $(\mathrm{c})$ & $(\mathrm{d})$ & $(\mathrm{e})$ & $(\mathrm{f})$ \\
Variables & Ex-Communist & Other Left & Liberal & Center-Right & Conservative & Nationalist \\
\hline TURNOUT & $.624^{*}$ & .115 & -.080 & -.071 & -.068 & $-.230^{*}$ \\
& $(.296)$ & $(.159)$ & $(.198)$ & $(.326)$ & $.210)$ & $(.099)$ \\
LAGVOTE & -.260 & .309 & -.040 & -.277 & -.261 & $-.329^{*}$ \\
& $(.245)$ & $(.179)$ & $(.367)$ & $(.284)$ & $(.208)$ & $(.141)$ \\
INC. & -3.76 & -9.81 & .920 & -3.99 & 2.09 & -4.76 \\
& $(6.01)$ & $(6.88)$ & $(4.11)$ & $(6.41)$ & $(3.39)$ & $(3.45)$ \\
ECON & .075 & .198 & .108 & .452 & -.101 & -.051 \\
& $(.351)$ & $(.111)$ & $(.207)$ & $(.320)$ & $(.320)$ & $(.092)$ \\
ECON*INC. & .241 & -.972 & -.525 & $-1.03 *$ & .023 & .028 \\
& $(.700)$ & $(.772)$ & $(.540)$ & $(.526)$ & $. .406)$ & $(.274)$ \\
CONSTANT & 8.43 & -4.48 & 17.98 & 9.01 & 19.18 & $16.00^{*}$ \\
& $(27.69)$ & $(11.52)$ & $(13.68)$ & $(24.21)$ & $(15.37)$ & $(7.04)$ \\
$\mathrm{R}^{2}$ & .82 & .82 & .67 & .81 & .89 & .97 \\
Adj. $\mathrm{R}^{2}$ & .61 & .60 & .27 & .59 & .78 & .94 \\
$\mathrm{~N}$ & 36 & 36 & 36 & 36 & 36 & 36 \\
\hline
\end{tabular}

Note: Dependent variable is vote for parties in each ideological category. Entries are unstandardized regression coefficients (standard errors). Table omits country dummies.

*Significant at .05 level.

insensitive to the influence of particular cases (for a discussion, see Western 1995). It is thus ideal for demonstrating that apparent findings are not artifacts arising from a few influential cases. Table 2 contains the results.

Substantive conclusions are much as before: The ex-communist and total-left continue to show positive, significant coefficients, while the nationalist and totalright remain negative and significant. The principal difference is that although turnout is still insignificant for the individual center party categories, the totalcenter vote shows a negative coefficient that, while modest in magnitude, is statistically different from zero.

It is telling, perhaps, that the results in Table 2 are remarkably consistent to changes in sample, as judged by reiteratively excluding all observations for each country (again, in the context of the more demanding robust estimation). The ex-communist, nationalist, and total-left, total-right, and total-center groupings continue to produce coefficients that are consistently significant and of the expected sign. The results for the other categories were also instructive. For the noncommunist left, turnout was insignificant but always positive; for the lib- 
TABLE 2

\section{Turnout and Party-Vote}

Post-Communist Europe, 1990-1999:

Robust Regression

\begin{tabular}{|c|c|c|c|c|c|c|c|c|c|}
\hline Variables & $\begin{array}{c}\text { (a) } \\
\text { Ex-Communist }\end{array}$ & $\begin{array}{c}\text { (b) } \\
\text { Other Left }\end{array}$ & $\begin{array}{c}\text { (c) } \\
\text { Liberal }\end{array}$ & $\begin{array}{c}\text { (d) } \\
\text { Center-Right }\end{array}$ & $\begin{array}{c}\text { (e) } \\
\text { Conservative }\end{array}$ & $\begin{array}{c}\text { (f) } \\
\text { Nationalist }\end{array}$ & $\begin{array}{c}(\mathrm{g}) \\
\text { Total Left }\end{array}$ & $\begin{array}{c}\text { (h) } \\
\text { Total Center }\end{array}$ & $\begin{array}{l}\text { (i) } \\
\text { Total Right }\end{array}$ \\
\hline TURNOUT & $\begin{array}{l}.545^{* * *} \\
(.139)\end{array}$ & $\begin{array}{l}.109 \\
(.114)\end{array}$ & $\begin{array}{l}-.180 \\
(.204)\end{array}$ & $\begin{array}{l}.046 \\
(.269)\end{array}$ & $\begin{array}{l}.031 \\
(.202)\end{array}$ & $\begin{array}{l}-.141^{*} \\
(.059)\end{array}$ & $\begin{array}{l}.967^{* *} \\
(.310)\end{array}$ & $\begin{array}{r}-.453^{*} \\
(.198)\end{array}$ & $\begin{array}{r}-.327^{*} \\
(.184)\end{array}$ \\
\hline LAGVOTE & $\begin{array}{r}-.037 \\
(.111)\end{array}$ & $\begin{array}{r}-.066 \\
(.121)\end{array}$ & $\begin{array}{l}-.054 \\
(.378)\end{array}$ & $\begin{array}{r}-.041 \\
(.235)\end{array}$ & $\begin{array}{r}-.164 \\
(.201)\end{array}$ & $\begin{array}{l}-.097 \\
(.104)\end{array}$ & $\begin{array}{r}-.095 \\
(.191)\end{array}$ & $\begin{array}{l}-.095 \\
(.194)\end{array}$ & $\begin{array}{c}-.172 \\
(.162)\end{array}$ \\
\hline INCUMB. & $\begin{array}{l}-1.62 \\
(2.82)\end{array}$ & $\begin{array}{c}12.56 \\
(30.46)\end{array}$ & $\begin{array}{l}-.750 \\
(4.23)\end{array}$ & $\begin{array}{c}7.84 \\
(5.30)\end{array}$ & $\begin{array}{r}.527 \\
(3.27)\end{array}$ & $\begin{array}{l}-2.98 \\
(2.14)\end{array}$ & $\begin{array}{l}-.161 \\
(4.82)\end{array}$ & $\begin{array}{c}-3.24 \\
(3.39)\end{array}$ & $\begin{array}{c}3.91 \\
(3.35)\end{array}$ \\
\hline ECON & $\begin{array}{l}.187 \\
(.166)\end{array}$ & $\begin{array}{l}.082 \\
(.075)\end{array}$ & $\begin{array}{r}-.047 \\
(.214)\end{array}$ & $\begin{array}{l}.556^{*} \\
(.264)\end{array}$ & $\begin{array}{r}-.014 \\
(.308)\end{array}$ & $\begin{array}{r}-.029 \\
(.055)\end{array}$ & $\begin{array}{l}.179 \\
(.252)\end{array}$ & $\begin{array}{l}-.186 \\
(.218)\end{array}$ & $\begin{array}{l}-.382 \\
(.337)\end{array}$ \\
\hline ECON* INCUMB. & $\begin{array}{l}.380 \\
(.329)\end{array}$ & $\begin{array}{c}1.16 \\
(2.76)\end{array}$ & $\begin{array}{r}-.449 \\
(.557)\end{array}$ & $\begin{array}{r}-.801^{*} \\
(.435)\end{array}$ & $\begin{array}{l}.196 \\
(.391)\end{array}$ & $\begin{array}{r}-.316^{*} \\
(.178)\end{array}$ & $\begin{array}{l}1.04 \\
(.918)\end{array}$ & $\begin{array}{l}-.294 \\
(.438)\end{array}$ & $\begin{array}{c}.413 \\
(.409)\end{array}$ \\
\hline CONSTANT & $\begin{array}{c}3.33 \\
(13.04)\end{array}$ & $\begin{array}{c}-5.11 \\
(8.23)\end{array}$ & $\begin{array}{c}23.90 \\
(14.11)\end{array}$ & $\begin{array}{c}1.57 \\
(20.01)\end{array}$ & $\begin{array}{c}11.87 \\
(14.80)\end{array}$ & $\begin{array}{c}9.85^{*} \\
(4.16)\end{array}$ & $\begin{array}{c}-21.78 \\
(27.67)\end{array}$ & $\begin{array}{l}42.39^{*} \\
(13.64)\end{array}$ & $\begin{array}{c}34.38^{*} \\
(14.11)\end{array}$ \\
\hline
\end{tabular}

Note: Dependent variable is vote for parties in each ideological category. Entries are robust regression coefficients (standard errors). Table omits country dummies.

*Significant at .05 level.

**Significant at .01 level.

***Significant at .001 level. 
eral parties it was consistently negative, though again insignificant; for the centerright and conservative parties, the coefficients changed erratically in sign and were always both tiny in magnitude and completely lacking in statistical significance.

Given the above evidence, we conclude that there is a strong and positive relationship between turnout and the share of the vote received by the total-left and by ex-communist parties in particular. In every case, the turnout coefficients for these parties were large and highly significant. If the ex-communists (and perhaps other leftist parties to a lesser degree) are improving their share of the vote, other parties are obviously suffering as a consequence. The clear losers are the nationalist parties (and, perhaps, other conservative parties). While the data are less consistent, it also seems that the center parties (and liberal parties in particular) also pay for the gains of the left.

\section{Discussion}

Our analysis suggests two obvious implications. The first is simply that electoral competition in the former communist nations of Europe appears, within the admittedly very limited theoretical concerns at hand, to be converging toward established patterns in Western liberal democracies. Such a conclusion must, of course, be made with some caution. Parties are still in the process of institutionalizing, and electoral volatility throughout the region remains high. Overall levels of party identification also tend to be relatively low (though perhaps increasing), with most parties in a state of institutional flux regardless of identity (Jungmann et al. 1993; Mateju 1995). Nonetheless, party-citizen relationships may be more commensurate with those observed in the advanced industrial countries than journalistic common sense would suggest.

The more immediate conclusion is a more practical one: Party fortunes are partially dependent upon rates of electoral participation. The notion that the left, and reformed communist parties in particular, benefit from higher turnout, while right-wing parties, and nationalists especially, tend to lose calls into question common assumptions about post-communist politics. It has been a widely held belief among scholars that, given that some of the most ardent supporters of the left, such as pensioners, are among the most likely citizens to vote (e.g., Kapstein and Mandelbaum 1997), the leftist parties should benefit from lower turnout. Our analysis suggests instead that the electoral success of the left in the former communist world is dependent upon high turnout, just as it is often argued to be in the West.

Indeed, our findings suggest that the left is even more dependent upon turnout than in the West. Pacek and Radcliff (1995), for example, report that every percentage point increase in turnout elevates the leftist vote by just under onethird of a percentage point for the industrial democracies. The statistical results reported here suggest that the turnout effect in the post-communist states of Europe is two to three times as pronounced, based upon results in column ( $\mathrm{g}$ ) of Table 2 . 


\section{Robert E. Bohrer II, Alexander C. Pacek, and Benjamin Radcliff}

The evidence offered here may also suggest an explanation for two observations that are less consistent with the established view that the leftist party constituents are "highly participatory." If they were, then one might expect a greater communist-successor comeback than we have seen. Instead, those ex-communist governments that we have seen were quickly defeated (Lithuania 1996, Poland 1997, and Hungary 1998). Similarly, one might have expected increased mass action aimed at slowing or stopping the economic reforms - events that have also generally failed to occur.

More to the point, if the ex-communist and leftist vote covaries with turnout, then such parties have a vested interest in removing disincentives to voting, as well as in creating or maintaining including electoral rules, such as proportional representation (see Moraski and Loewenberg 1999), which may alter the costs and benefits of voting (e.g., Powell 1986). Conversely, parties of the right may in turn favor such impediments to turning out. The manner in which these debates are transformed into policy outcomes may have profound consequences for the ongoing process of democratic consolidation across the region.

Manuscript submitted 27 July 1998

Final manuscript received 6 March 2000

\section{References}

Aguilar, Edwin Eloy, and Alexander Pacek. 1997. "Voter Turnout, Macroeconomic Conditions, and Working Class/Economically Disadvantaged Party Support." Paper presented at the annual meeting of the Western Political Science Association, Tucson, Arizona.

Bahry, Donna, and Lucan Way. 1994. "Citizen Activism in the Russian Transition."? Post-Soviet Affairs. 10(4): 330-66.

Banks, Arthur, Alan Day, Thomas Muller. 1998. Political Handbook of the World. Binghamton, NY: CSA Publications.

Blazyca, George. 1998. "The Politics of Economic Transformation." In Developments in Central and East European Politics, 2, eds. Stephen White, Judy Batt, and Paul G. Lewis. Durham, NC: Duke University Press.

Cline, Mary. 1993. "The Demographics of Party Support in Poland." RFE/RL Research Report. 2(36).

Cox, Terry. 1998. "The Politics of Social Change.” In Developments in Central and East European Politics 2, eds. Stephen White, Judy Batt, and Paul G. Lewis. Durham, NC: Duke University Press.

Dalton, Russell. 1996. Citizen Politics: Public Opinion and Political Parties in Advanced Industrial Democracies. $2^{\text {nd }}$ ed. Chatham, NJ: Chatham House.

Day, Alan, Richard German, and John Campbell. 1996. Political Parties of the World. $4^{\text {th }}$ ed. London: Cartermill.

Erikson, Robert. 1995a. "State Turnout and Presidential Voting: A Closer Look." American Politics Quarterly. 23(3): 387-96.

Erikson, Robert. 1995b."Pooling and Statistical Control: A Rejoinder to Radcliff." American Politics Quarterly 23(3): 404-8.

Evans, G., and S. Whitefield. 1993. "Identifying the Bases of Party Competition in Eastern Europe." British Journal of Political Science 23(3): 521-48.

Girnius, Saulius. 1992. "The Parliamentary Election in Lithuania." RFE/RL Research Report. 48(4).

Haraszti, Miklos. 1995. "Animal Farm Scenarios: The Comeback of the Former Communists and Why It Is No Reason to Worry." Constellations 2(1): 81-93. 
Heyns, Barbara, and Ireneusz Bialecki. 1991. "Solidarnosc: Reluctant Vanguard or Makeshift Coalition?" American Political Science Review 85(2): 351-70.

Huber, John, and Ronald Inglehart. 1995. "Expert Interpretation of Party Space and Party Locations in 42 Societies." Party Politics 1: 73-111.

Ishiyama, John. 1995. "Communist Parties in Transition: Structures, Leaders, and Processes of Democratization in Eastern Europe." Comparative Politics 27(1): 147-66.

Ishiyama, John. 1997. "The Sickle or the Rose?: Previous Regime Types and the Evolution of the Ex-Communist Parties in Post-Communist Societies." Comparative Political Studies 30(2): 299-330.

Janos, Andrew. 1994. "Continuity and Change in Eastern Europe: Strategies of Post-Communist Politics." East European Politics and Society 8(4): 1-31.

Jasiewicz, Krzysztof. 1993. "Polish Politics on the Eve of the 1993 Elections: Toward a Fragile Pluralism." Communist and Post-Communist Studies. 26(4): 387-411.

Jungmann, Bohumil, Stanislav Hampl, Jan Herzmann, Ivan Tomak, and Vladimira Kobylkova. 1993. Volby 1992. Prague: Institut pro Vyzkum Verejneho Mineni.

Kapstein, Ethan, and Michael Mandelbaum, eds. 1997. Sustaining the Transition: The Social Safety Net in Postcommunist Europe. New York: Council on Foreign Relations Press.

Kitschelt, Herbert. 1992. "The Formation of Party Systems in East Central Europe." Politics and Society 20(1): 7-50.

Kolosi, Tamas, Ivan Szelenyi, Szonja Szelenyi, and Bruce Western. 1992. "The Making of Political Fields in Post-Communist Transition: Dynamics of Class and Party in Hungarian Politics, 19891990." In Post-Communist Transition: Emerging Pluralism in Hungary, eds. Andras Bozoki, Andras Korosenyi, and George Schopflin. New York: St. Martins Press.

Korosenyi, Andras. 1992. "Revival of the Past or New Beginnings? The Nature of Post-Communist Politics." In Post-Communist Transition: Emerging Pluralism in Hungary, eds. Andras Bozoki, Andras Korosenyi, and George Schopflin. New York: St. Martins Press.

Lijphart, Arend. 1997. "Unequal Participation: Democracy's Unresolved Dilemma." American Political Science Review 91(1): 1-14.

Mackie, Thomas. 1995. "Parties and Elections." In Governing the New Europe, eds. Jack Hayward and Edward C. Page. Durham, NC: Duke University Press.

Mahr, Allison, and John Nagle. 1995. "Resurrection of Successor Parties and Democratization in East-Central Europe." Communist and Post-Communist Studies. 28(4): 393-409.

Markowski, Radoslaw. 1993. "Non-Voters: The Polish Case." In The Political Culture of Eastern Europe, ed. George Meyer. Tubingen, Germany: Franke-Verlag.

Markowski, Radoslaw. 1997. "Political Parties and Ideological Space in East-Central Europe." Communist and Post-Communist Studies 30(3): 221-54.

Mateju, Petr. 1995. "In Search of Explanations for Recent Left Turns in Post-Communist Countries." In Research Project: Social Stratification in Eastern Europe after 1989. Prague: Institute of Sociology, Academy of Sciences of the Czech Republic.

McAllister, Ian. 1986. "Compulsory Voting, Turnout, and Party Advantage in Australia. Politics. 21(2): 89-93.

McAllister, Ian, and Anthony Mughan. 1986. "Differential Turnout and Party Advantage in British General Elections." Electoral Studies 5(3): 143-52.

Millard, Frances. 1992. "The Polish Parliamentary Elections of October 1991.” Soviet Studies 44(5): $837-55$.

Moraski, Bryon, and Gerhard Loewenberg. 1999. "The Effect of Legal Thresholds on the Revival of Former Communist Parties in East Central Europe." Journal of Politics 61(2): 151-70.

Nagel, Jack. 1988. "Voter Turnout in New Zealand General Elections, 1928-1988." Political Science 40(2): 16-38.

Nagel, Jack, and John McNulty. 1996. "Partisan Effects of Voter Turnout in Senatorial and Gubernatorial Elections." American Political Science Review 90(3): 780-93.

Oppenhuis, Erik Vincent. 1995. Voting Behavior in Europe: A Comparative Analysis of Electoral Participation and Party Choice. Amsterdam: Het Spinhuis. 


\section{Robert E. Bohrer II, Alexander C. Pacek, and Benjamin Radcliff}

Pacek, Alexander. 1994. "Macroeconomic Conditions and Electoral Politics in East Central Europe." American Journal of Political Science 38(3): 723-44.

Pacek, Alexander, and Benjamin Radcliff. 1995. "Turnout and the Left-Party Vote." British Journal of Political Science 25(1): 137-53.

Plasser, Fritz, Peter Ulram, and Harald Waldrauch. 1998. Democratic Consolidation in EastCentral Europe. New York: St. Martins Press.

Powell, G. Bingham. 1986. "American Voter Turnout in Comparative Perspective." American Political Science Review 80(1): 17-43.

Powers, Denise, and James Cox. 1997. "Echoes of the Past: The Relationship Between Satisfaction with Economic Reforms and Voting Behavior in Poland." American Political Science Review 91(3): $617-34$.

Radcliff, Benjamin. 1992. "The Welfare State, Turnout, and the Economy: A Comparative Analysis." American Political Science Review 86(2): 444-56.

Radcliff, Benjamin. 1994. "Turnout and the Democratic Vote." American Politics Quarterly 22(2): 259-76.

Radcliff, Benjamin. 1995. "Turnout and the Vote Revisited: A Reply to Erikson." American Politics Quarterly 23(3): 397-403.

Rose, Richard. 1997. "Evaluating Voter Turnout." (www.int-idea.se/publications/voter_1.htm).

Rosenstone, Stephen. 1982. "Economic Adversity and Voter Turnout." American Journal of Political Science 26(1): 27-46.

Sakwa, Richard. 1995. "The Russian Elections of December 1993." Europe-Asia Studies. 47(1): $195-227$.

Seligson, Mitchell, Annabelle Conroy, Ricardo Cordova, Macia Orlando J. Perez, and Andrew Stein. 1995. "Who Votes in Central America? A Comparative Analysis." In Elections and Democracy in Central America, Revisited, eds. Mitchell Seligson and John Booth. Chapel Hill: University of North Carolina Press.

Tucker, Harvey, and Arnold Vedlitz. 1986. "Does Heavy Turnout Help Democrats in Presidential Elections?" American Political Science Review 80(4): 1291-98.

Tworzecki, Hubert. 1996. Parties and Politics in Post-1989 Poland. Boulder, CO: Westview Press.

Voter Turnout from 1945-1997: A Global Report on Political Participation. 1997. Stockholm: Institute for Democracy and Electoral Assistance.

Wade, Larry, Peter Lavelle, and Alexander Groth. 1995. "Searching for Voting Patterns in PostCommunist Poland's Sejm Elections." Communist and Post-Communist Studies 28(4): 411-25.

Weatherford, Stephen. 1978. "Economic Conditions and Electoral Outcomes." American Journal of Political Science 22(3): 917-38.

Western, Bruce. 1995. "Concepts and Suggestions for Robust Regression Analysis." American Journal of Political Science 39(3): 786-817.

Whitefield, Stephen, and Geoffrey Evans. 1994. "The Russian Election of 1993: Public Opinion and the Transition Experience." Post-Soviet Affairs 10(1): 38-60.

Zubek, Voytek. 1994. "The Reassertion of the Left in Post-Communist Poland." Europe-Asia Studies 46(5): 801-38.

Robert E. Bohrer II is assistant professor of political science, Gettysburg College, Gettysburg, PA 17325.

Alexander C. Pacek is associate professor of political science, Texas A\&M University, College Station, TX 77843-4348.

Benjamin Radcliff is associate professor of political science, University of Notre Dame, Notre Dame, IN 46556-0368. 